\title{
Quick Correction of a Skeletal Class III Maloclussion in Primary Dentition with Face Mask Plus Rapid Maxillary Expansion Therapy
}

\section{Corrección rápida de una maloclusión esquelética clase III en dentición primaria con máscara facial más terapia rápida de expansión maxilar}

\author{
Hilda Alejandra Bedolla-Gaxiola DDS1; David Garrigós-Esparza DDS1; \\ Juan Carlos Hernández-Cabanillas DDS, MS²; Miguel Ángel Rosales-Berber DDS"; \\ Amaury Pozos-Guillén DDS, PhD¹; José Arturo Garrocho-Rangel DDS, PhD1
}

1. Pediatric Dentistry Postgraduate Program, Faculty of Dentistry, San Luis Potosi University, San Luis Potosi, SLP. México. 2. Faculty of Dentistry, Baja California University, Tijuana, BC, México.

Correspondence to: Dr. José Arturo Garrocho-Rangel - agarrocho@hotmail.com

Received: 16-VII-2017
Published Online First: 12-II-2018

DOI: https://doi.org/10.15517/ijds.v0i0.32381

\section{ABSTRACT}

Skeletal Class III is a malocclusion characterized by anterior crossbite as a result of an abnormal skeletal maxillary and mandibular base discrepancy, which involves disharmony of craneofacial skeleton and profile. The preferred management for children having skeletal Class III malocclusion with retruded maxilla and/or prognathic mandible is the use of devices that encourage the growth and anterior movement of the maxilla bone and/or restrict the exessive mandible growth. The orthopedic treatment consisting of a face mask with rapid maxillary expansion (RME) produces the most dramatic results in the shortest period of time. The purpose of this article is to review a quick correction of skeletal class III maloclussion in the primary dentition through a case example with use of a face mask plus rapid maxillary expansion therapy in a 5 year-old male patient due to a combination of retruded maxilla and protruded mandible, in primary dentition, who was treated with a Petit face mask in conjunction with a bonded RME intraoral appliance added with bite blocks. The first evident occlusal outcomes were a clockwise rotation of the mandible, a positive overjet of $3 \mathrm{~mm}$, a correct overbite, a canine Class I relationship, and a bilateral flush terminal plane. After discussing the present clinical case report and the related published literature, we concluded that skeletal class III malocclusions should be treated as soon as the first clinical signs of abnormal craniofacial growth are recognized, during the first years of life.

\section{KEYWORDS}

Skeletal class III; Malocclusion; Primary dentition; Rapid maxillary expansion. 


\section{RESUMEN}

La clase III esquelética es una maloclusión caracterizada por mordida cruzada anterior como resultado de una discrepancia esquelética de la base maxilar y mandibular, que implica desarmonía craneofacial y del perfil. El tratamiento de elección para niños con maloclusión clase III esquelética con mandíbula maxilar y/o prognática es el uso de dispositivos que estimulan el crecimiento y el movimiento anterior del hueso maxilar y/o restringen el crecimiento excesivo de la mandíbula. El tratamiento ortopédico que consiste en una máscara facial con expansión maxilar rápida (EMR) produce resultados en un período de tiempo más corto. El propósito de este artículo es revisar una corrección rápida de la maloclusión de clase III esquelética en la dentición primaria mediante el uso de una máscara facial más terapia de expansión maxilar rápida en un paciente masculino de 5 años debido a una combinación de maxilar retruido y mandíbula prominente, en dentición primaria, que fue tratada con una mascarilla Petit junto con un dispositivo intraoral unido con bloques de mordida. Los primeros resultados evidentes fueron una rotación en sentido horario de la mandíbula, un overjet positivo de $3 \mathrm{~mm}$, una sobremordida correcta, una relación canina de Clase I y un plano terminal de descarga bilateral. Después de discutir el presente informe de caso clínico y la literatura publicada relacionada, concluimos que las maloclusiones de clase III esqueléticas deberían tratarse tan pronto como se reconozcan los primeros signos clínicos de crecimiento craneofacial anormal, durante los primeros años de vida.

\section{PALABRAS CLAVE}

Clase III esquelética; Maloclusión; Dentición primaria; Expansión maxilar rápida.

\section{INTRODUCTION}

An adequate guidance of the eruption of the primary, mixed, and permanent dentitions, and the craneofacial growth and development, is an integral component of comprehensive oral healthcare for all pediatric dental patients. Early diagnosis and treatment of developing malocclusions may render long-term benefits, while providing a functional occlusion together with an esthetic/harmonic dentofacial configuration (1). Skeletal Class III malocclusions (SCIII) is a growth abnormality related to the craneofacial morphology, which increase with age if left untreated (1-3). It is characterized by maxillary deficiency and/or mandibular prognathism, accompanied by an anterior crossbite or edgeto-edge incisor relationship, or a dentoalveolar compensation consisting of retroclination of lower incisors and proclination of upper incisors $(2,4$ $6)$; other common features are the presence of narrowed upper arch and posterior crossbite (7). In around $70 \%$ of cases, this type of malocclusion exhibits maxillary retrognathism with midface deficiency $(3,8)$.

The etiology of the SCIII can be hereditary, environmental or both. Hereditary factors include palate/alveolar clefts as well as other craniofacial syndromes. Environmental factors that may play a significant role are oral habits like mouth breathing, trauma or a forward/downward positioned tongue $(1,5,7,9)$. The reported incidence of the malocclusion varies among the ethnic groups; for example, it is highest in Asians (4-14\%), while in Latin-Americans and Afro-americans is $5 \%$, in Europeans 3-8\%, and in Caucasians 1-4\% $(4,5,9,10)$. Diagnosis of the skeletal discrepancy is based on a careful observation of a sequence of facial, occlusal, and cephalometric characteristics; however, in children the diagnostic process may be difficult because this malocclusion is not 
totally defined, with facial and occlusal features no yet well established $(1,10)$. Thus, the skeletal malocclusion should be distinguished from other similar presentations, including the functional crossbite by occlusal prematurities or pseudoClass III due to abnormal incisal guidance $(1,6,7)$.

The interceptive correction of this type of malocclusion in growing children remains as a challenge part of the contemporary pediatric dentistry and orthodontics practice (7). The main treatment approaches recommended in the dental literature for SCIII in children, adolescents and young adults are the maxillary rapid expansion (RME), face masks, functional orthopedic intraoral appliances (e.g. Reverse Twin-Block, Monoblock, FR-III appliance, or Class III Bionator or Bimler appliances), multibracket fixed appliances, splints with interarch Class III elastics, cervical extraoral mandibular anchoring, tooth extractions, and a combination of orthodontics and orthognathic surgery $(11,12)$. Regarding to this, the dental literature evidence shows great variability in the actual results obtained when these therapies are applied in children and adolescents (6). The aim of the present clinical case report was to describe and discuss the management and follow-up of a young child with a SCIII malocclusion due to a combination of retruded maxilla and prognathic mandible, treated with a combination of face mask and an intraoral bonded appliance for RME to correct the anterior crossbite and modulate the craniofacial growth.

\section{CLINICAL CASE REPORT}

A Mexican 5.1 year old-boy came to the Pediatric Dentistry Postgraduate Program Clinic with the chief complaint of anterior crossbite and prominent lower teeth. Parents manifested that a child's grandfather had a similar malocclusion. Medical history with no relevant information. On extraoral examination, the facial profile was convex, without facial asymmetry, anterior divergent face, competent lips, lower lip relatively protruded, and acute nasolabial angle (Fig.1). Intraoraly, the patient exhibited several enamel white spot lesions but not evident caries cavities; his primary dentition occlusion showed interdental spaces, a bilateral exaggerated mesial terminal plane and Class III canine relationship, anterior crossbite of the four primary incisors (overjet-5 $\mathrm{mm}$ and deep reverse overbite+3.5 $\mathrm{mm}$ ); the upper arch exhibited a normal width. Functional examination no exhibited premature contact points, and oral hygiene and gingival conditions were considered as acceptable. His smile was unpleasent because the lack of display of upper incisors (Fig.2).

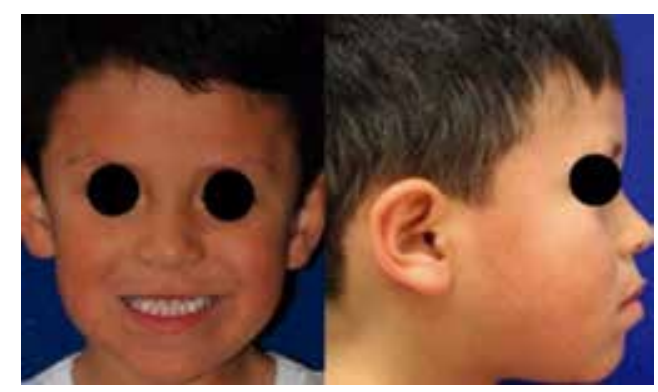

Figure 1. Pretreatment extraoral images.

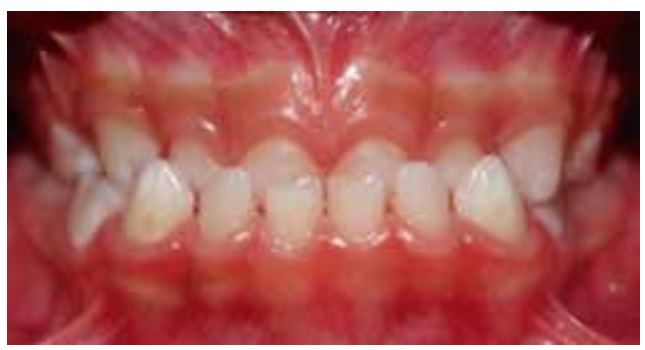

Figure 2. Pretreatment intraoral anterior view.

The panoramic x-ray findings exposed the presence of a complete permanent dental germs, with no abnormal dental or intrabony conditions. The Steiner and Jaraback cephalometric analyses revealed that the child had a SCIII malocclusion due mainly to mandibular prognathism $\left(S N B=85^{\circ}\right.$, normal $\left.=77-79^{\circ}\right)$ and a slighlty retruded maxilla $\left(\mathrm{SNA}=77^{\circ}\right.$, normal $=78-82^{\circ}$; with tendency towards a horizontal growth pattern (Sum of N-S-Ar or Saddle angle+S-Ar-Go or Articulare angle+Ar-GoMe or Gonial angle $=386^{\circ}$, normal $=396^{\circ}$ ), short 
cranial base ( $\mathrm{N}-\mathrm{S}$ distance $=59 \mathrm{~mm}$ ), and reverted lower lip (facial esthetic line $=+4 \mathrm{~mm}$ ) (Fig.3). So, the orthopedic treatment was aimed to attain a positive overjet (i.e. to correct the incisor crossbite) and normal overbite and establish a functional occlusion, redirect the mandible growth toward a downward and backward direction to improve the intermaxillary skeletal relationship, obtain a esthetic smile, and follow-up the patient's remaining growth to assess the need for further treatment.

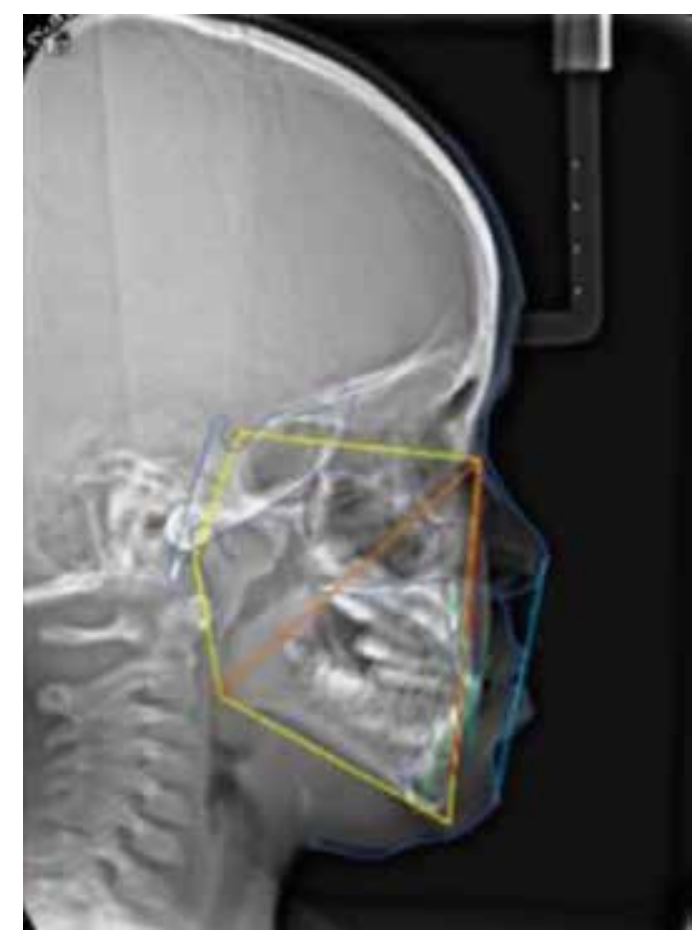

Figure 3. Cephalometric analyses.

The patient was treated with a Petit face mask to move forward the maxilla and to restrict the mandibular growth, in conjunction with a intraoral bonded maxillary acrylic appliance with bite blocks ("McNamara Appliance") for RME (Fig.4). The expansion screw was activated 2 turns every day for two weeks. Two metallic hooks were positioned bilaterally between the primary canine and first molar, to engage the elastics. The face mask was placed after one week of RME. The appliance was carefully adjusted to patient's forehead and chin, and extraoral 5/16 inch (13 oz) elastics were placed for one week (in the second week they were subtituted by $14 \mathrm{oz}$ elastics), 30 downward in relation to the occlusal plane, to the face mask attachment framework. The orthopedic force exerted by the elastics was $400 \mathrm{~g}$ per side, measured by a Dontrix gauge. The patient was instructed to use the appliance for a minimum of 12 to 14 hours daily, and the expansion screw was activated only twice a day. Compliance from the patients and his parents throughout the treatment has been excellent. Patient was actively treated for five weeks, until an overjet of $3 \mathrm{~mm}$ was achieved, developing a correct overbite, Class I canine relationship, flush terminal planes, and a well settled occlusion (Fig.5). There was also an evident improvement in the smile. Post-treatment cephalometric measurements did not exhibit significant changes; only the SNB angle decreased $1^{\circ}$.
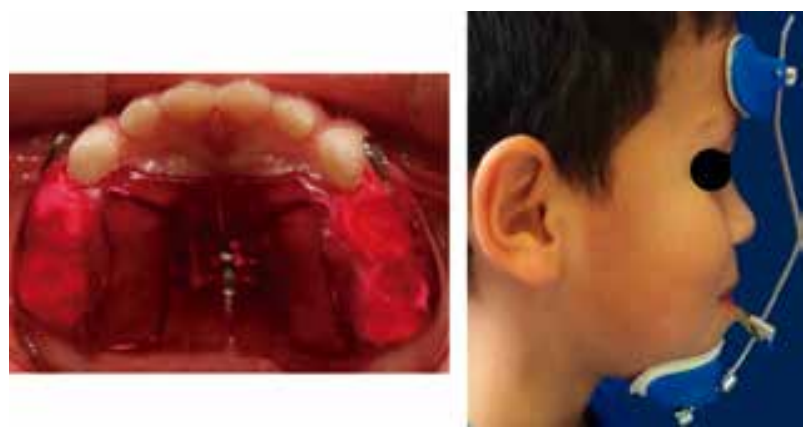

Figure 4. McNamara intraoral appliance and Petit face mask.

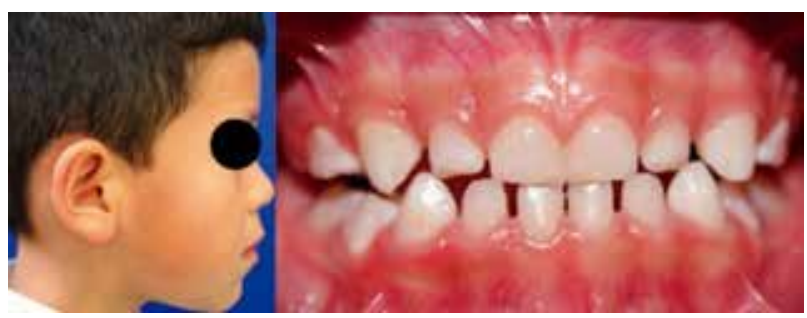

Figure 5. Postreatment face profile and intraoral images.

The face mask is still being worn only at nights as retention, to restrain the mandible growth. The intraoral McNamara appliance was substituted by a removable fan-shaped maxillar expander with occlusal blocks, which was activated three times a week, for a wider anterior expansion. The child will 
be closed monitored until all major facial growth is complete.

\section{DISCUSSION}

In the skeletal Class III malocclusion case reported here, we could achieve a favorable treatment response by reestablishing the skeletal, facial, and occlusal environments. A mild but favorable clockwise rotation of the mandible was observed. The normal incisal relationship achieved had a significant impact on the facial lower half soft tissue esthetics. The treatment delivered provided thus a more pleasing craniofacial appearance, with better lip posture and competence. At this respect, Sarver has mentioned that instead of cephalometric relationships or measurements, "... it is the soft tissue that ultimately directs our treatment directions and decision-making" (13).

The clinical objectives of the early treatment of skeletal Class III malocclusion in young children include the growth redirection and modulation during the most active stages of dental and craniofacial development, and thus, the prevention of progressive abnormal hard and soft tissue changes (1). Besides, the craneofacial anomalies mentioned abvove, diverse dental abnormalities have been reported when the crossbite remains uncorrected, such as excessive wear of the lower incisors, thinning of the vestibular alveolar plate, and gingival recession $(1,2,9)$. The clinical findings of the present case report tend to confirm the effectiveness of the combination Petit face mask plus a RME as orthopedic therapy for SCIII in very early dentition stages.

However, the skeletal Class III malocclusion in children has raised controversies among clinicians concerning diagnosis, prognosis and management, and definitive treatment tends to be delayed $(10,14)$. According to Major and El-Badrawy (15) and Ngan and Hon-Yin (5) many practitioners avoid early treatment of this malocclusion due to their inhability to predict mandible growth and to the belief that the condition is caused only by a mandibular overgrowth and, therefore, the orthognathic surgery will be inevitable; others still employ old management strategies such as chin cup devices, attempting to restrict the mandibular growth, with limited stability and high probabilities of relapse (14). Based on the dental literature, the best current non-surgical management approach for children exhibiting early signs of a SCIII with maxillary deficiency includes the dentofacial growth modification through a Petit face mask protraction orthopedic device (3-5). The Petit face mask obtains anchorage from the forehead and chin, interconnected by a vertical steel rod, and exerts a protraction force on maxillary hooks -in the present case, placed in the upper canine/first molar region of the intraoral bonded appliance-, making the upper arch as a single unit. Then, an extraoral force of 400-600 g per side is applied through bilateral elastics which are positioned in a $30^{\circ}$ angle downward to an adjustable horizontal heavy steel support framework, placed on the vertical rod $(9,12)$. The face mask is worn 14 hours a day and the elastics are changed daily (11). According to the American Association of Pediatric Dentistry (1), before starting the orthopedic intervention with the Petit face mask it is neccesary to carefully assess some individual factors such as: (i) facial growth pattern; (ii) amount of the antero-posterior of skeletal and dental discrepancy; (iii) patient age and her/his projected level of compliance; and (iv) space analysis. Even, clinicians can know how to early predict the future mandibular growth of a pediatric patient with SCIII for an adequate treatment planning (5). The Petit face mask increases the facial height and establish a more favorable environment for the anterior and vertical growth of the maxilla, accompanied by addition of bone tissue at posterior sutures $(3,4,7,11)$. Additionally, it induces downward and backward of the mandible, decreasing the prominence of the chin $(3,4,14)$; the technique also produces dental changes: maxillary teeth are forward moved while 
lower incisors are retracted (11). The addition of a bonded RME appliance for rapid expansion of the maxilla midline suture is frequently needed in order to increase the upper arch transverse width, reducing thus the severity of malocclusion $(7,9)$; it also produces a disarticulation of the circummaxillary suture system (fronto, naso, inter, ethmoido, zygomatico, and lacrimomaxillary; zygomaticotemporal and pterygopalatine (16), allowing a more efficient protraction of the maxilla $(12,14)$. In the present case this intraoral appliance was fabricated in conjunction with bite blocks, allowing a quicker anterior crossbite resolution. Thus, the simultaneous use of the face mask and the RME appliance with bite blocks is more effective in early dentition stages (late deciduous or early mixed), especially with regard to the magitude of both skeletal and dentofacial changes; this can be explained because the bone tissue is best modified during those phases of rapid growth, and the circummaxillary sutures are patent in children until eight years old $(2,9,12,17)$. However, it is strongly encouraged a long-term follow up of the trated patient until craniofacial growth is complete (12). Furthermore, a meta-analysis by Kim et al. (18) related to the treatment of SCIII, concluded that the average treatment duration with the face mask and RME appliance was significantly shorter compared to the non-expansion group. On the other hand, although it has been demonstrated that the maxilla can remain stable for around two years after treatment, Abraham et al. (12) recommend an overcorrection to 3 to $4 \mathrm{~mm}$ overjet, overall in cases of excessive mandibular growth.

According to previous reports, in addition to the maxillary forward displacement, other craniofacial substantial favorable changes have been observed when face mask and RME with bite blocks are applied together in young children; for example, in the region of the pterigomaxillary suture, as a result of bony apposition in the maxillay tuberosity $(12,17)$. Likewise, and according to Nang and colleagues, this therapeutic combination can help eliminate any centric occlusion/centric relation discrepancy to reveal the true underlying skeletal abnormality. On the other hand, Al-Khalifa (11) reported that the main cephalometric changes produced after treatment are the significant average improvements of the SNA, SNB and ANB angles, the overjet, the molar relationship, and the Wits appraisal (or the distance between th two points of intersection of the two perpendicular lines from points $A$ and $B$ to functional occlusal plane).

\section{CONCLUSIONS}

Early treatment of SCIII-during the primary dentition stage-, with the face mask plus a RME appliance with bite blocks may provide a more favorable environment for craneofacial and dental structures, achieving satisfactory and long-term stable functional and esthetic changes, and potentially to decrease the risk of a future orthognathic surgery. As in the preset case, this combined therapy can improve the child's profile and self-image, together with other psychosocial benefits, provided the selected management plan is based on an adequate diagnosis and the treatment is implemented early, during the first years of life; of course, it is also indispensable the absolute compliance during the treatment from the child and her/his parents.

\section{REFERENCES}

1. American Academy of Pediatric Dentistry. Guideline of management of the developing dentition and occlusion in pediatric dentistry. Pediatr Dent. 2016; 17 (6): 253-65.

2. Maheshwari S., Gupta N. D. Early treatment of skeletal Class III: A case report. J Indian Soc Pedod Prev Dent. 2001; 19 (4): 148-51.

3. Zhang W., Qu H. C., Yu M., Zhang Y. The effects of maxillary protraction with or without rapid maxillary expansion and age factors in treating Class III maloclusion: A metaanalysis. Plos One. 2015; 10 (6): e0130096. 
4. Kapust A. J., Sinclair P. M., Turley P. K. Cephalometric effects of face mask/ expansion therapy in Class III children: A comparison of three age groups. Am J Orthod Dentofac Orthop. 1998; 113 (2): 204-12.

5. Ngan P., Hon-Yin S.. Early treatment of Class III patients to improve facial aesthetics and predict future growth. Honk Kong Dent J. 2004; 1: 24-30.

6. Solano-Mendoza B., Iglesias-Linares A., Yañez-Vico R. M., Mendoza-Mendoza A., Alió-Sanz J. J., Solano-Reina E. Maxillary protraction at early ages. The revolution of new bone anchorage appliances. J Clin Pediatr Dent. 2012; 37 (2): 219-29.

7. Karthi M., Gobichettipalayam J. A., Bhandari P. K.. Early correction of Class III malocclusion with rapid maxillary expansion and face mask therapy. J Pharm Bioallied Sci. 2013; 5 (Suppl 2): S169-72.

8. Ellis E., McNamara Jr J. A.. Components of adult Class III open-bite malocclusion. Am J Orthod. 1984; 86 (4): 277-90.

9. Singh K., Verma V. K., Panda S., Sachan A. Management of skeletal Class III malocclusion in an early mixed dentition with face mask therapy: A case report. J Dent Res Updates. 2014; 1 (1): 55-60.

10. Rodrigues de Almeida M., Rodrigues de Almeida R., Oltramari-Navarro P. V., Ferreira-Conti A. C., de Lima-Navarro R., Camacho J. G. Early treatment of Class III maloclussion: 10-year clinical follow-up. J Appl Oral Sci. 2011; 19 (4): 431-9.
11. Al-Khalifa H. N. Orthopedic correction of Class III malocclusion during mixed dentition. Open J Stomatol. 2014; 4: 372-80.

12. Abraham A., Peter E., Philip K., Mukundan V., Geoge J., Sreevatsan R. Early management of Class III malocclusion with bonded maxillary expansion and facemask therapy. A case report. Int Den J Stud Res. 2016; 4 (4): 202-6.

13. Sarver D. M. The face as the determinant of treatment choice. From Frontiers of dental and facial esthetics. Craniofacial Growth Series, 38. McNamara \& Kelly Eds. 2001.

14. Kanno Z., Kim Y., Soma K. Early correction of a developing skeletal Class III malocclusion. Angle Orthod. 2007; 77 (3): 549-56.

15. Major P. W., El-Badrawy H. E. Maxillary protraction for early orthopedic correction of skeletal Class III malocclusion. Pediatr Dent. 1993; 15 (3): 203-7.

16. Ngan P. Treatment of Class III malocclusion in the primary and mixed dentition. In: Bishara S. Textbook of Orthodontics. Saunders, 375414, 2003.

17. Baccetti T., McGill J. S., Franchi L., McNamara Jr J. A., Tollaro I. Skeletal effects of early tratment of Class III malocclusion with maxillary expansion and face-mask therapy. Am J Orthod Dentofac Orthop. 1998; 113 (3): 333-43.

18. Kim J. H., Viana M. A., Graber T. M., Omerza F. F., BeGole E. A. The effectiveness of protraction face mask therapy: A metaanalysis. Am J Orthod Dentofac Orthop. 1999; 115 (6): 675-85. 